Gelanggang Olahraga: Jurnal Pendidikan Jasmani dan Olahraga

Volume 3, Nomor 1, Juli-Desember 2019

e-ISSN : 2597-6567

p-ISSN : 2614-607X

DOI : https://doi.org/10.31539/jpjo.v3i1.862

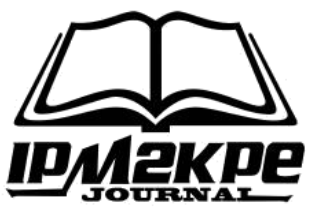

\title{
MENINGKATKAN HASIL BELAJAR PASSING BAWAH BOLA VOLI MELALUI BERMAIN MELEMPAR BOLA
}

\author{
Deka Ismi Mori Saputra', Gusniar ${ }^{2}$ \\ STKIP Muhammadiyah Muara Bungo ${ }^{122}$ \\ dekaismimori@gmail.com $^{1}$
}

\begin{abstract}
ABSTRAK
Tujuan penelitian ini adalah untuk mengetahui penerapan bermain melempar bola untuk meningkatkan pembelajaran passing bawah bola voli pada siswa Kelas IV SD 85/II Apung Mudik.Penelitian menggunakan rancangan penelitian tindakan kelas yang dilaksanakan dalam dua siklus, tiap siklus terdiri dari perencanaan, pelaksanaan tindakan, observasi dan refleksi.Subjek penelitian ini adalah siswa Kelas IV, berjumlah 20 siswa. Data hasil pembelajaran bola voli diperoleh melalui tes unjuk kerja, lembar observasi digunakan untuk mengumpulkan data kegiatan siswa di dalam mengikuti proses pembelajaran bola voli dengan metode melempar bola.Hasil penelitian ini diperoleh berdasarkan penilaian tiga aspek yaitu psikomotor, afektif, dan kognitif.Hasil penelitian terdapat peningkatan yang signifikan dari kondisi siklus I ke siklus II. Hasil penilaian, pada siklus I 58,62\% dalam kategori tuntas jumlah siswa yang tuntas adalah 15 siswa. Pada siklus II terjadi peningkatan siswa dalam kategori tuntas sebesar 82,76\% dengan jumlah siswa yang tuntas adalah 18 siswa. Simpulan, bermain melempar bola dapat meningkatkan hasil belajar passing bawah bola voli
\end{abstract}

Kata Kunci: Hasil Belajar, Melempar Bola,Passing Bawah

\section{ABSTRACT}

The purpose of this study was to determine the application of playing throwing a ball to improve the learning of passing under volleyball for Class IV Elementary 85 / II Floating Mudik students. The study used a class action research design which was carried out in two cycles, each cycle consisting of planning, action implementation, observation and reflection. The subjects of this study were Class IV students, totaling 20 students. Volleyball learning outcomes data obtained through performance tests, observation sheets are used to collect data on student activities in following the volleyball learning process with the throwing ball method. The results of this study were obtained based on an assessment of three aspects, namely psychomotor, affective, and cognitive. The results of the study showed a significant improvement from cycle I to cycle II. The results of the assessment, in the first cycle $58.62 \%$ in the complete category the number of students who completed was 15 students. In cycle II there was an increase in students in the complete category by $82.76 \%$ with the number of students who completed was 18 students. Conclusion, playing throwing a ball can improve learning outcomes under volleyball passing

Keywords: Learning Outcomes, Throwing the Ball, Passing Down 


\section{PENDAHULUAN}

Konsep dasar pendidikan jasmani dan model pembelajaran pendidikan jasmani yang efektif perlu dipahami oleh guru yang hendak mengajar pendidikan jasmani.Pendidikan Jasmani sebagai komponen pendidikan secara keseluruhan telah disadari oleh banyak kalangan.Namun dalam pelaksanaannya pengajar pendidikan jasmani berjalan belum efektif seperti yang diharapkan.Pembelajaran pendidikan jasmani cenderung tradisional.Model pembelajaran pendidikan jasmani tidak harus terpusat pada guru, tetapi pada siswa. Orientasi pembelajaran harus disesuaikan, dengan perkembangan anak, isi dan urusan materi serta cara penyampaian harus disesuaikan sehingga menarik dan menyenangkan, sasaran pembelajaran ditujukan bukan hanya mengembangkan keterampilan olahraga, tetapi pada perkembangan pribadi anak seutuhnya.

Permainan bola voli sekarang sudah berkembang dengan pesatnya, baik di dunia insternasional maupun di Indonesia sendiri.Hal ini merupakan modal dasar bagi PBVSI khususnya dan pembina voli pada umumnya untuk terus mengembangkan serta meningkatkan mutu olahraga bola voli nasional.Salah satu usaha untuk mengembangkan pembinaan bola voli adalah dengan menerapkan teknik dasar voli sedini mungkin kepada anak-anak sekolah dasar melalui pembelajaran bola voli di sekolah.Pembelajaran voli di tingkat sekolah dasar sangat dibutuhkan dalam menunjang program pemerintah dalam mewujudkan prestasi PBVSI.Untuk memaksimalkan potensi yang ada pada setiap atlit maka pembinaan kondisi fisik atlit dalam suatu pertandingan harus optimal, berkenaan dengan ini Harsono (1988) mengemukakan yang harus di perhatikan, dalam Praseason, yaitu musim latihan jauh sebelumnya pertandingan berbagai komponen kondisi fisik haruslah dilatih agar pada waktu atlit memasuki musim latihan berikut yaitu early dan mead season, dia sudah mencapai kondisi fisik.

Permainan bola voli terdapat teknik dasar yang meliputi servis, passing, smash, block. Teknik teknik tersebut biasanya teknik servis yang harus di kuasai oleh suatu regu bola voli karena servis mempunyai potensi besar dan menghasilkan point untuk meraih kemenangan. Melakukan teknik passing dengan baik merupakan hal yang sangat penting untuk menghasilkan point, karena passing yang tidak efektif akan mengakibatkan kekalahan bagi sebuah tim bola voli. Pelaksanaan pembelajaran pendidikan jasmani dalam kegiatan di sekolah perlu ditingkatkan guna untuk menjawab keraguan dan kegelisahaan masyarakat sebagai orang tua terhadap relevansi materi pendidikan jasmani di sekolah. Namun sering terjadi proses pembelajaran pendidikan jasmani di sekolah, hasilnya tetap tidak optimal. Hal ini mungkin dikarenakan kemungkinan gerak siswa yang rendah.

Menurut Inarman dan Tono (2013) setiap aktivitas siswa pada pembelajaran passing bawah dengan menggunakan metode pembelajaran latihan lempar tangkap bola, mengalami peningkatan dari setiap siklusnya. Ketuntasan belajar siswa berdasarkan hasil tes akhir, menurut (Standar sekolah) dari 22 siswa,pada siklus I tindakan I terdapat 8 siswa yang tidak tuntas, dan siswa yang tuntas belajarnya dengan jumlah prosentase ketuntasan sebesar 59,09\%, sedangkan kriteria ketuntasan hasil belajar pada siklus I Tindakan II terdapat 7 siswa yang tidak tuntas dan yang tuntas belajarnya 15 siswa dengan prosentase ketuntasan sebesar $68,18 \%$. Siklus II Tindakan I terdapat 4 siswa yang tidak tuntas dan siswa tuntas ada 18 siswa dengan prosentase ketuntasan sebesar 
$81.82 \%$, di siklus II Tindakan II ada 2 siswa yang tidak tuntas dan 20 siswa yang tuntas dengan prosentase ketuntasan sebesar 90,91\%. respon siswa pada pembelajaran dengan menggunakan metode lempar tangkap bola pembelajaran passing bawah hasilnya positif. Sedangkan menurut Wijatmiko (2012) hasil belajar passing bawah meningkat setelah dilakukan tindakan yang berupa pembelajaran passing bawah dengan menggunakan bola dari siklus 1 sampai siklus 2.

Sedangkan hasil penelitian Sovensi (2018) menyatakan terdapat hubungan yang signifikan antara koordinasi mata tangan dan ekstensi togok secara bersamasama dengan ketepatan smash. Kemudian hasil penelitian Supriyanto (2018) menyatakan pemain yang memiliki kecepatan reaksi tinggi lebih efisien dilatih dengan metode latihan beban, sedangkan pemain yang memiliki kecepatan reaksi rendah lebih efisien dilatih dengan metode latihan plyometric.

Pada penelitian ini difokuskan pada peningkatan hasil belajar passing bawah melalui lempar bola pada siswa sekolah dasar. Teknik dasar voli yang diajarkan di sekolah dapat menjadi pembinaan tahap awal.Pembelajaran voli di sekolah dasar bertujuan untuk siswa dapat mencapai puncak prestasi yang diharapkan.Untuk mencapai tujuan tersebut diperlukan pembelajaran yang dapat memotivasi siswa dan pembelajaran yang bersifat menarik dan menyenangkan.Akan tetapi pembelajaran voli di SD masih banyak mengalami kendala, baik itu dari internal maupun eksternal.

Berdasarkan hasil survey peneliti sekaligus guru penjaskes di Sekolah Dasar pembelajaran pendidikan jasmani yang ada saat ini belum menubuhkan minat siswa, sesuai dengan tingkat pertumbuhan dan perkembangan peserta didik, baik dari segi kognitif, motorik, afektif dan fisik. Model pembelajaran yang tidak sesuai karakteristik anak, tidak ada kreativitas akan membuat anak merasa bosan, sehingga anak tidak bergairah untuk melakukan pembelajaran. Sebagai contoh pada pembelajaran voli.Pembelajaran seringkali tidak sesuai karakteristik anak, sehingga kreativitas kesenangan anak tidak terfikirkan.Hal tersebut membuat pembelajaran yang kurang maksimal sehingga hasil pembelajarannya juga kurang maksimal.

\section{KAJIAN TEORI}

\section{Teknik Dasar Passing Bawah}

Passing bawah yaitu passing yang dilakukan dengan dua tangan yang dikaitkan, dengan ayunan dan perkenaan dari bawah lengan, perkenaan bola pada bagian proximal pergelangan tangan dengan bidang selebar mungkin agar bola tidak banyak membuat putaran. Menurut Paneo (2014) teknik dasar passing bawah antara lain :

1. Sikap Permulaan. Sikap berdiri normal yaitu kedua kaki dibuka dengan kedua lutut ditekuk dan badan sedikit dibengkokkan ke depan, badan menumpu pada kaki bagian depan agar lebih mudah dan cepat bergerak ke segala arah.

2. Pelaksanaan. Setelah bola dipukul posisi badan kembali berdiri normal (tegak) dan diikuti dengan gerakan badan dan langkah kaki ke depan koordinasi tetap terjaga dengan baik. Latihan passing bawah dapat dilakukan secara berpasangan atau kelompok dua orang yang lebih, sesuai dengan jumlah bola yang ada 


\section{Bermain Melempar Bola}

Bermain melempar bola menurut Lestari (2015) terdiri dari:

1. Permainan Pertama (Permainan Lempar Bola)

a. Siswa dibagi menjadi dua baris yang saling berhadapan dan berada diluar garis lapangan.

b. Masing-masing membawa bola plastik untuk mengeluarkan sekumpulan bola kecil yang ada didalam lingkaran dengan cara dilempar

c. Pemenang dalam lomba apabila salah satu kelompok lebih banyak mengeluarkan bola yang ada di dalam lingkaran.

d. Permainan berlangsung selama 10 menit, dan saling melempar bola yang ada di dalam lingkaran.

2. Permainan Kedua (Lempar Bola Sasaran)

a. Guru menyuruh siswa untuk berbaris dan saling berhadapan.

b. Tiap baris disiapkan bola, kemudian setelah mendengar aba-aba dari guru siswa mulai melempar bola kearah sasaran yang berada di tengahtengah antara barisan sap.

c. Bola ditembakkan ke arah sasaran agar bola sasaran bisa melewati garis batas lemparan.

d. Regu yang menang apabila bola sasaran bisa melewati batas lemparan regu lawan.

e. Permainan berlangsung 10 menit dan saling bergantian.

3. Permainan Ketiga (Permainan Mengumpulkan Poin)

a. Siswa dibagi menjadi dua kelompok

b. Guru membuat lapangan bola voli yang ditulisi dengan angka 1 sampai 5

c. Setiap siswa melakukan servis satu kali.

d. Jatuhnya bola menunjukkan nilai yang diperoleh.

e. Barisan ke dua, ketiga dan seterusnya dijumlahkan sampai peserta habis, regu yang dianggap menang adalah regu yang paling banyak memperoleh pengumpulan angka dari hasil servis yang dilakukan

f. Siswa dibagi menjadi dua kelompok dengan tiap kelompok terdiri dari 8 dan 7 siswa.

g. Siswa disiapkandalam lapangan bola voli mini masing-masing kelompok, permainan seperti permainan bola voli tetapi bola menggunakan bola plastik, selain itu siswa memukul bola dengan teknik servis bawah, dan dilakukan dalam lomba selama 10 menit, Guru memberi aba-aba mulai, siswa yang mampu mengenai sasaran. Kelompok yang mendapat nilai terbanyak sebagai juara.Tujuan dari permainan ini adalah untuk memberikan rasa senang, percaya diri, keberanian dan bersaing dalam penguasaan servis bawah dan supaya siswa membiasakan diri terhadap bola dan lapangan permainan

4. Permainan Keempat (Servis Bawah Berkelompok)

a. Guru memancang net pada kedua tiang di dua lapangan bola voli mini dengan ukuran tinggi $2 \mathrm{~m}, 1$ lapangan untuk putra dan 1 lapangan untuk putri kemudian diberi sasaran.

b. Siswa dibagi menjadi dua kelompok untuk putra dan putri. 
c. Siswa disiapkan dalam lapangan voli mini masing-masing kelompok permainan seperti permainan voli tetapi menggunakan bola plastik, selain itu siswa pertama-tama melakukan servis bawah.

d. Kelompok lain menerima bola dengan dua tangan dan dilempar dengan servis bawah.

e. Setiap bola mati maka yang melakukan servis diganti yang berbaris dibelakangnya, demikian sampai barisan habis.

f. Regu yang berhasil mematikan bola mendapat nilai satu (1) kelompok yang mendapat nilai terbanyak sebagai juara dan kegiatan ini dilakukan selama 10 menit. Berdasarkan beberapa permainan melempar bola di atas, diharapkan siswa dapat menguasai teknik servis bawah bola voli dengan baik, karena bentuk-bentuk permainan melempar sangat menyerupai teknik servis bawah bola voli. Proses pembelajaran ini untuk memberikan rasa senang, percaya diri, keberanian dan bersaing dalam penguasaan servis bawah dan supaya siswa membiasakan diri terhadap bola dan lapangan permainan.

\section{METODE PENELITIAN}

Penelitian ini menggunakan rancangan penelitian tindakan (Classroom Action Research), secara garis besar terdapat empat tahapan yang lazim dilalui dalam penelitian tindakan kelas yaitu (1) perencanaan, (2) pelaksanaan, (3) pengamatan, dan (4) refleksi.

\section{Perencanaan}

Sebelum melaksanakan kegiatan penelitian ada beberapa kegiatan perencanaan yang mesti dipersiapkan diantaranya adalah:

1. Mempersiapkan silabus, tujuan pembelajaran, sistem penilaian dan mempersiapkan skenario pembelajaran yang dimuat dalam RPP berkenaan dengan materi pembelajaran

2. Mempersiapkan format observasi, alat tes dan instrument lain untuk mengetahui ketercapaian hasil pembelajaran bola voli pada kompetensi dasar yang diteliti.

3. Menyiapkan sumber belajar yang berupa materi pembelajaran yang diteliti dan buku sumber.

4. Mengembangkan skenario pembelajaran dengan menggunakan pendekatan melempar bola pada materi ajar tersebut.

\section{Pelaksanaan}

Dalam pelaksanaan kegiatan pembelajaran Penjaskes dengan pendekatan metode melempar bola maka guru akan merencanakan dua siklus pembelajaran. Adapun tahap-tahap pada setiap siklus adalah sebagai berikut :

1. Guru melakukan apersepsi dan memberikan motivasi untuk mengarahkan siswa memasuki Standar Kompetensi dan Kompetensi Dasar yang akan dibahas.

2. Guru menjelaskan tujuan pembelajaran yang harus dicapai oleh siswa setelah proses pembelajaran berakhir.

3. Guru menyajikan materi pembelajaran. 
4. Guru memberikan tugas kepada siswa untuk dikerjakan secara individu.

5. Guru memberikan tes pasiing bawah bolavoli kepada siswa.

6. Guru memberikan evaluasi.

7. Guru beserta siswa mengambil kesimpulan diakhir pembelajaran.

\section{Pengamatan}

Langkah-langkah pengamatan dan observasi yang dilakukan dalam penelitian ini yaitu sebagai berikut :

1. Peneliti dan kolaborator mengamati proses pelaksanaan pembelajaran passingbawah bola voli dengan menggunakan metode pembelajaran melempar bola kepada siswa.

2. Peneliti dan kolaborator melakukan pengamatan dan penilaian terhadap hasil belajar siswa

\section{Refleksi}

Setelah kegiatan pengamatan maka data-data yang diperoleh akan diolah berdasarkan jenis data dan kebutuhan penelitian. Deskripsi yang diperoleh dari kegiatan ini kemudian akan direfleksikan guru dalam menyelenggarakan pembelajaran selanjutnya. Semua kegiatan pembelajaran dengan pendekatan pembelajaran melempar bola ini akan diselenggarakan secara sistematis berdasarkan pemetaan siklusnya.

Data yang diperoleh dianalisa dengan cara menghitung frekuensi siswa yang menjawab benar setiap soal yang diberikan, kemudian dihitung rata-rata hasil belajar pada akhir siklus. Untuk mengetahui adanya peningkatan hasil belajar siswa adalah cara membandingkan rata-rata yang diperoleh dari siklus sebelumnya. Dari hasil perbandingan yang diperoleh dijadikan sebagai bahan pertimbangan untuk menyusun rencana tindakan perbaikan pada siklus berikutnya.

\section{HASIL PENELITIAN}

Pada kondisi awal ditemukan hasil ketuntasan $65,52 \%$ yang belum tuntas. Sebagai dasar perencanaan siklus pertama. Peneliti melakukan kegiatan perbaikan dengan menggunakan prosedur pada siklus I melalui : perencanaan (planing), tindakan (acting) dan refleksi (evaluasi).Deskripsi nilai akhir siswa setelah nilai kognitif, afektif dan psikomotor digabungkan dan dibagi tiga.

Tabel 1

Deskripsi Nilai Akhir

\begin{tabular}{cccc}
\hline \multirow{2}{*}{ ASPEK } & \multicolumn{2}{c}{ SIKLUS 1 } & \\
& PERSENTASE & JUMLAH SISWA & KRITERIA \\
\multirow{2}{*}{ NILAI AKHIR } & $58,62 \%$ & 13 & Tuntas \\
& $41,38 \%$ & 7 & Tidak Tuntas \\
\hline
\end{tabular}

Untuk lebih jelasnnya hasil belajar yang didapatkan siswa pada data awal dan akhir siklus I pada diagram dibawah ini. 


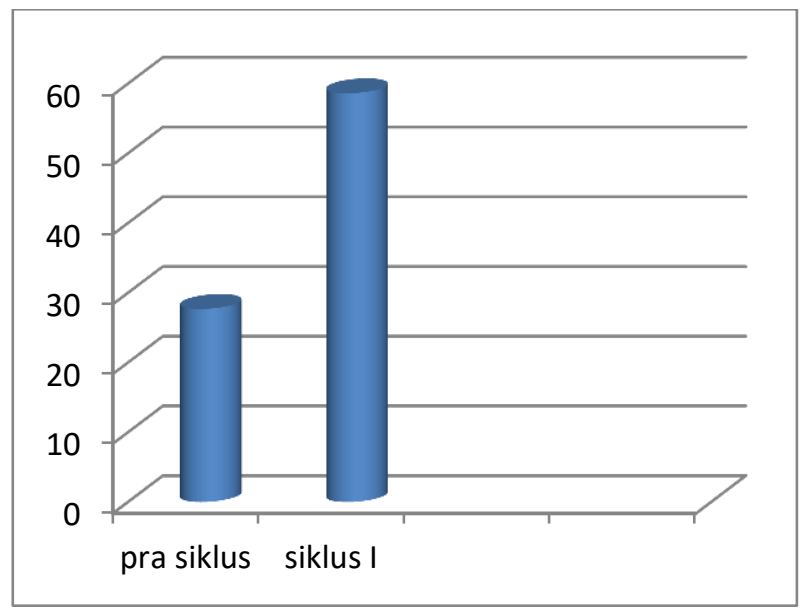

Gambar 1 Grafik Perbandingan Hasil Belajar Siswa Pra siklus \& Siklus I

Grafik perbandingan hasil belajar siswa diatas menunjukan bahwa penerapan pembelajaran passing bawah melalui melempar bola memberikan banyak manfaat kepada siswa kelas IV SD Negeri 85/II Apung Mudik .Dilihat dari grafik tersebut adanya peningkatan pada pra siklus ke siklus siklus I.

Tabel 2

Deskripsi Nilai Akhir Siswa Setelah Nilai Kognitif, Afektif dan Psikomotor

\begin{tabular}{cccc}
\hline \multirow{2}{*}{ ASPEK } & \multicolumn{2}{c}{ SIKLUS II } & \\
& PERSENTASE & JUMLAH SISWA & KRITERIA \\
NILAI AKHIR & $82,76 \%$ & 18 & Tuntas \\
& $17,24 \%$ & 2 & Tidak Tuntas \\
\hline
\end{tabular}

Untuk lebih jelasnnya hasil belajar yang didapatkan siswa pada data awal dan akhir siklus II pada diagram dibawah ini.

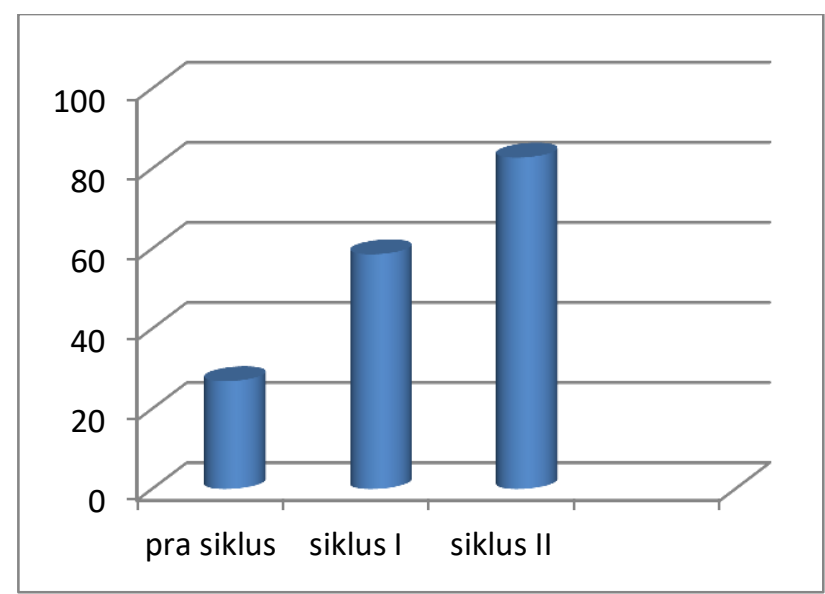

Gambar 2. Grafik Perbandingan Hasil Belajar Siswa Pra Siklus, Siklus I dan Siklus II 
Grafik perbandingan hasil belajar siswa diatas menunjukan bahwa penerapan pembelajaran passing bawah melalui melempar bola memberikan banyak manfaat kepada siswa kelas IV SD Negeri 85/II Apung Mudik .Dilihat dari grafik tersebut adanya peningkatan pada setiap siklus.

\section{PEMBAHASAN}

Hasil penelitian menunjukan bahwa pembelajaran passing bawah bola voli melalui melempar bola dapat meningkatkan hasil belajar siswa. Hal ini selaras dengan teori yang telah dikemukakan pada kajian teori yaitu oleh Paneo (2014) mengenai teknik dasar passing bawah dengan indikator-indikator passing bawah bola voli yaitu dengan menggunakan latihan melempar bola dapat meningkatkan hasil belajar siswa. Bermain melempar menggunakan bola dalam penelitian ini sebagai berikut:

1. Permainan Pertama (Permainan Lempar Bola)

a. Siswa dibagi menjadi dua baris yang saling berhadapan dan berada diluar garis lapangan.

b. Masing-masing membawa bola plastik untuk mengeluarkan sekumpulan bola kecil yang ada didalam lingkaran dengan cara dilempar

c. Pemenang dalam lomba apabila salah satu kelompok lebih banyak mengeluarkan bola yang ada di dalam lingkaran.

d. Permainan berlangsung selama 10 menit, dan saling melempar bola yang ada di dalam lingkaran.

2. Permainan Kedua (Lempar Bola Sasaran)

a. Guru menyuruh siswa untuk berbaris dan saling berhadapan.

b. Tiap baris disiapkan bola, kemudian setelah mendengar aba-aba dari guru siswa mulai melempar bola kearah sasaran yang berada di tengahtengah antara barisan sap.

c. Bola ditembakkan ke arah sasaran agar bola sasaran bisa melewati garis batas lemparan.

d. Regu yang menang apabila bola sasaran bisa melewati batas lemparan regu lawan.

e. Permainan berlangsung 10 menit dan saling bergantian.

3. Permainan Ketiga (Permainan Mengumpulkan Poin)

a. Siswa dibagi menjadi dua kelompok

b. Guru membuat lapangan bola voli yang ditulisi dengan angka 1 sampai 5

c. Setiap siswa melakukan servis satu kali.

d. Jatuhnya bola menunjukkan nilai yang diperoleh.

e. Barisan ke dua, ketiga dan seterusnya dijumlahkan sampai peserta habis, regu yang dianggap menang adalah regu yang paling banyak memperoleh pengumpulan angka dari hasil servis yang dilakukan

f. Siswa dibagi menjadi dua kelompok dengan tiap kelompok terdiri dari 8 dan 7 siswa.

g. Siswa disiapkandalam lapangan bola voli mini masing-masing kelompok, permainan seperti permainan bola voli tetapi bola menggunakan bola plastik, selain itu siswa memukul bola dengan teknik servis bawah, dan dilakukan dalam lomba selama 10 menit, Guru memberi aba-aba mulai, siswa yang mampu mengenai sasaran. 
Kelompok yang mendapat nilai terbanyak sebagai juara.Tujuan dari permainan ini adalah untuk memberikan rasa senang, percaya diri, keberanian dan bersaing dalam penguasaan servis bawah dan supaya siswa membiasakan diri terhadap bola dan lapangan permainan

4. Permainan Keempat (Servis Bawah Berkelompok)

a. Guru memancang net pada kedua tiang di dua lapangan bola voli mini dengan ukuran tinggi $2 \mathrm{~m}, 1$ lapangan untuk putra dan 1 lapangan untuk putri kemudian diberi sasaran.

b. Siswa dibagi menjadi dua kelompok untuk putra dan putri.

c. Siswa disiapkan dalam lapangan voli mini masing-masing kelompok permainan seperti permainan voli tetapi menggunakan bola plastik, selain itu siswa pertama-tama melakukan servis bawah.

d. Kelompok lain menerima bola dengan dua tangan dan dilempar dengan servis bawah.

e. Setiap bola mati maka yang melakukan servis diganti yang berbaris dibelakangnya, demikian sampai barisan habis.

f. Regu yang berhasil mematikan bola mendapat nilai satu (1) kelompok yang mendapat nilai terbanyak sebagai juara dan kegiatan ini dilakukan selama 10 menit. Berdasarkan beberapa permainan melempar bola di atas, diharapkan siswa dapat menguasai teknik servis bawah bola voli dengan baik, karena bentuk-bentuk permainan melempar sangat menyerupai teknik servis bawah bola voli. Proses pembelajaran ini untuk memberikan rasa senang, percaya diri, keberanian dan bersaing dalam penguasaan servis bawah dan supaya siswa membiasakan diri terhadap bola dan lapangan permainan.

Masih banyaknya siswa yang belum tuntas disebabkan oleh beberapa faktor diantaranya masih ada siswa yang tidak serius dalam mengikuti pelajaran dan adanya faktor luar seperti penjual mainan yang berjualan di area sekolahan yang mengakibatkan siswa tidak fokus.

Pada siklus I masih belum tercapai pembelajaran tuntas sehingga perlu di lakukan refleksi untuk kegiatan pada siklus II. Dalam pelaksanaan siklus II ini telah dapat memperkecil kelemahan-kelemahan pada siklus I, dan nilai rata-rata siswa juga sudah meningkat. Kemungkinan dengan adanya melempar bola maka siswa tidak bosan untuk melaksanakan kegiatan.

Pada siklus II, guru terlebih dahulu mengulang kembali pembelajaran passing bawah bola voli menggunakan melempar bola, dengan demikian siswa akan lebih aktif untuk memperoleh nilai hasil belajar yang lebih baik. Selain itu peneliti dan guru pengamat mengawasi jalanya kegiatan pembelajaran pada setiap individu secara bergantian, sehingga jika terdapat kesulitan siswa langsung dapat bertanya pada guru. Dari hasil evaluasi pada siklus II, hasil belajar siswa telah mencapai $82,76 \%$. Hal ini menunjukan bahwa pembelajaran tuntas telah tercapai.Berdasarkan data yang diperoleh tersebut maka dapat diketahui bahwa pembelajaran passing bawah sangat diperlukan suatu media pembelajaran, agar siswa mengalami langsung belajar secara individu dan menjadi semangat untuk mengikuti pembelajaran.Khususnya pada materi passing bawah, tepat sekali menggunakan melempar bola. Pada setiap siklus penelitian dari pengamatan situasi belajar siswa tentang aktivitas siswa terhadap melempar bola yang 
dilakukan dengan hasil tes pada akhir siklus telah meningkat dari 58,62\% pada siklus I menjadi $82,76 \%$ pada siklus II.

Peningkatan hasil belajar siswa sebenarnya sangat berkaitan dengan keinginan siswa itu sendiri untuk belajar, faktor penunjang kegiatan pembelajaran dan media pembelajaran itu sendiri. Karena dengan meningkatnya aktivitas siswa tehadap penggunaan melempar bola yang telah dilaksanakan sangatlah berpengaruh terhadap hasil belajar siswa tersebut, ini dapat dilihat dari perubahan terhadap hasil belajar siswa tersebut dan perubahan setiap siklusnya. Dengan telah di capainya ketuntasan belajar pada siklus II, maka tidak perlu lagi dilakukan refleksi untuk kegiatan siklus selanjutnya, dengan demikian penelitian tindakan kelas pada konsep passing bawah bola voli sudah tuntas tidak perlu di lanjutkan lagi ke siklus berikutnya.

\section{SIMPULAN}

Dengan menggunakan pembelajaran passing bawah bola voli melalui melempar bola dapat meningkatkan hasil belajar siswa dalam materi pembelajaran passing bawah bola voli pada siswa sekolah dasar

\section{DAFTAR PUSTAKA}

Harsono, M. S., \& Drs, M. S. (1988). Coaching dan Aspek-aspek Psikologis dalam Coaching. Direktorat Jendral Pendidikan Tinggi: Jakarta.

Inarman, I., Hartanto, H., \& Tono, S. (2013). Meningkatkan Passing Bawah Dalam Permainan Bola Meningkatkan Passing Bawah Dalam Permainan Bola Voli Melalui Latihan Lempar Tangkap Bola Pada Siswa Kelas V SD Negeri 98 Bengkulu Selatan (Doctoral dissertation, Fakultas Keguruan dan Ilmu Pendidikan Universitas Bengkulu).

Lestari. (2015). Upaya Peningkatan Pembelajaran Servis Bawah Melalui Pendekatan Bermain Melempar Dalam Permainan Bolavoli Mini Pada Siswa Kelas IV SD Negeri Tegalrandu Kabupaten Magelang. UNY

Paneo, R. P. (2014). Meningkatkan Kemampuan Gerak Dasar Passing Bawah Pada Permainan Bola Voli Melalui Metode Berpasangan Siswa Kelas Iv Sdn I Hunggaluwa-Limboto (Doctoral dissertation, Universitas Negeri Gorontalo).

Sovensi, E. (2018). Ketepatan Smash Pemain Bolavoli Siswa SMA Ditinjau dari Koordinasi Mata-Tangan dan Extensi Togok. Gelanggang Olahraga: Jurnal Pendidikan Jasmani Dan Olahraga (JPJO), 2(1), 129-139. https://doi.org/https://doi.org/10.31539/jpjo.v2i1.406

Supriyanto, S. (2018). Pengaruh Metode Latihan Plyometric dan Latihan Beban dengan Kecepatan Reaksi terhadap Power Otot Tungkai Pemain Bolavoli Putra. Gelanggang Olahraga: Jurnal Pendidikan Jasmani Dan Olahraga (JPJO),

176-189. https://doi.org/https://doi.org/10.31539/jpjo.v2i1.423

Wijatmiko, A. (2012). Upaya Peningkatan Pembelajaran Passing Bawah Bolavoli Melalui Pendekatan Bermain Melempar Bola Pada Siswa Kelas IV SD Negeri I Kebokura Kecamatan Sumpiuh Kabupaten Banyumas Tahun 2011/2012. 